\title{
A Life History Approach to the Assessment and Management of Deepwater Fisheries in the Northeast Atlantic
}

\author{
M. W. Clarke, C. J. Kelly, P. L. Connolly and J. P. Molloy \\ Marine Institute \\ GTP, Parkmore, Galway, Ireland
}

\begin{abstract}
It has been generally stated that fish exploited by deepwater fisheries cannot sustain high levels of exploitation because of their characteristic slow growth, longevity and low reproductive output. Irish surveys (1993-2000) allowed for studies of age, growth, fecundity and maturity of several deepwater teleosts and elasmobranchs. These data show that the teleost roundnose grenadier Coryphaenoides rupestris is slow growing and has low fecundity. Other teleosts also displayed rather conservative life-history characteristics. The birdbeak dogfish shark Deania calceus was slower growing than the teleosts and leafscale gulper shark Centrophorus squamosus attained ages of up to 70 years. The implications of these life-history parameters for sustainable exploitation are discussed by way of comparison with continental shelf species from this region. These data allowed for the estimation of the rate of potential population increase that supports the view that deepwater species are more vulnerable to exploitation. Whilst there may be scope for compensatory changes in fecundity such scope is likely to be limited, especially for sharks. Fisheries management plans should consider these differing life-history traits. The very different life history strategies exhibited by shelf and deepwater species suggests that different management systems will be required for deepwater fisheries to those prosecuted on the shelf.
\end{abstract}

Keywords: age, black scabbardfish, deepwater fisheries, grenadier, growth, management, mortality, reproduction, shark, sustainability

\section{Introduction}

The International Council for Exploration of the Sea (ICES) defines deepwater fisheries as those in waters deeper than $400-500 \mathrm{~m}$. Such fisheries have developed rapidly in recent years in ICES Sub-divisions VI and VII (Fig. 1). This rapid expansion is due to the decline (or indeed collapse) of many traditional stocks. Some of these deepwater fisheries are long established, for example the Norwegian longline fishery for ling Molva molva and tusk Brosme brosme (Connolly et al., 1999) whilst others are by now well established, for example the pelagic trawl fisheries for blue whiting Micromesistius poutassou and greater argentine Argentina silus (Gordon, 2001). Others have developed in the last 10 years but are now quite advanced, such as the French mixed-species trawl fishery (Charuau et al., 1995) and the Spanish deepwater longline fisheries for sharks, forkbeard Phycis blennoides and mora Mora moro (Pineiro et al., 2001). In most recent years further expansions of fishing to grounds such as Hatton Bank for Greenland halibut Reinhardtius hippoglossoides, blue ling Molva dypterygia and sharks (Langedal and Hareide, MS 2000; Pineiro et al., 2001) have taken place.

ICES recognised the growing importance of these new fisheries and convened a Study Group (now a Working Group) in 1994. The advice from ICES based on the work of this group has consistently been to keep fishing effort at a low level until sufficient information is gathered to enable scientific-based management decisions (Gordon, 2001). The ICES management advice (Anon., MS 2001) made reference to two categories of deepwater stocks:

Category 1, Developing new fisheries:

"Consistent with a precautionary approach, fishing should not be allowed to expand faster than acquisition of information necessary to provide a basis for sustainable exploitation."

Category 2, Fully or overexploited fisheries:

"ICES recommends immediate reduction in these fisheries unless they can be shown to be sustainable." 


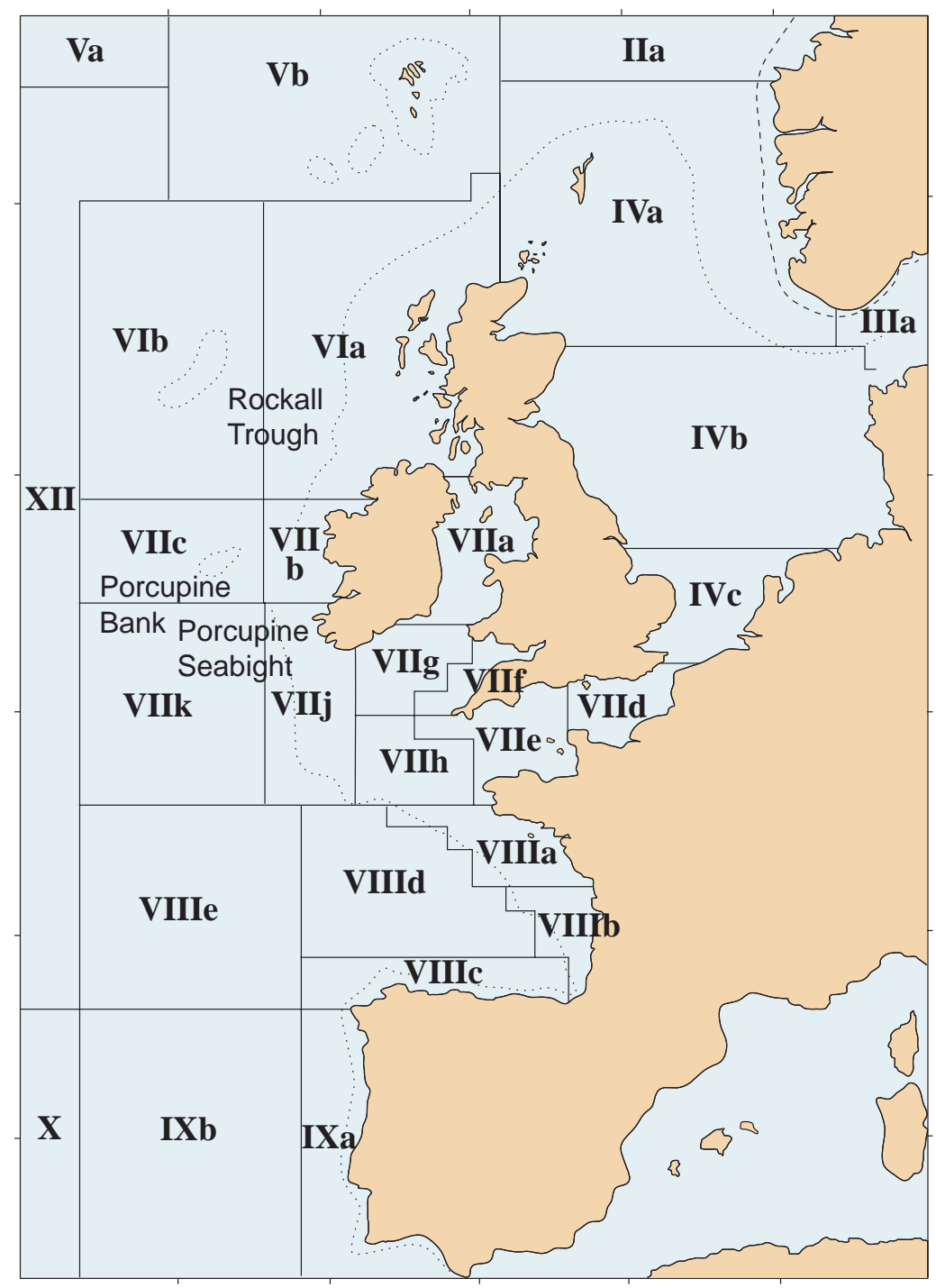

Fig. 1. Map of ICES Sub-areas and divisions, Northeast Atlantic, showing the study area; the Rockall Trough and slopes of Porcupine Bank and Seabight.

Stocks in Category 2 include most of stocks in ICES Sub-areas VI and VII. Notable exceptions in this area were greater forkbeard and the squalid sharks that were assigned to Category 1. This advice was intended to apply to virgin stocks. However this term is not entirely appropriate for forkbeard or the sharks, for which fishing has taken place for most of the 1990s.

Most deepwater fisheries developed recently. But already there is strong evidence from around the world that such fisheries may not be sustainable. It is unclear whether roundnose grenadier Coryphaenoides rupestris in the Northwest Atlantic will ever recover (Atkinson, 1995) and there is evidence that many stocks of orange roughy Hoplostethus atlanticus in New Zealand have followed a similar fate (Clark, 2001). It is clear that assembling data needed for conventional management will take a long time, in fact often longer than a deep-water fishery might be expected to last (Haedrich et al., 2001). Management advice should ideally be based on population dynamics, including fisheries-dependent and fisheries-independent data, for example abundance and biomass indices collected on an annual basis. Yet for deepwater species this sort of information is mostly lacking. 
Whilst great efforts have been taken to collect and refine time-series of catch and effort data, this process is only slowly allowing for assessments to be carried out. For deepwater stocks most of the data available relate to the life history of the target species. This paper presents the results of life history studies carried out at the Irish Marine Institute, over the last 10 years. Such information can in itself provide a framework for determining the sustainability of these species to exploitation. It is the purpose of this paper to use this information to inform the management process for these deepwater fisheries.

\section{Materials and Methods}

A deepwater survey program of the continental slopes of the Rockall Trough, Porcupine Bank and Porcupine Seabight was initiated in 1992. Together with data collected from commercial fishing vessels and port sampling, these surveys formed the basis of several primary biological studies of deepwater fish (Clarke, 2000; Kelly, 1997; Ronan et al., MS 1993). The species for study were chosen on the basis of their importance to commercial fisheries and their abundance, species being chosen from the main taxa and distributional patterns in the region.

Studies of age, growth, maturity and fecundity of roundnose grenadier Coryphaenoides rupestris were carried out using specimens collected from trawl surveys (1993-95) (Kelly et al., MS 1998). Age estimation, using sectioned sagittal otoliths, was conducted and estimates of the parameters of the von Bertalanffy growth model were obtained with respect to pre-anus length and total weight. Size-at-maturity - from probit modelling - and age-at-maturity estimates were also obtained (Kelly et al., 1997). Age estimation of juvenile $C$. rupestris was validated by analysis of the outer edge of the whole otoliths (Gordon et al., MS 1995b). Fecundity analysis of this species was carried out for females in the range $63-95 \mathrm{~cm}$ total length and in order to elucidate the reproductive cycle, an analysis of oocyte dynamics was also carried out (Kelly et al., 1996).

Age estimates of bluemouth rockfish Helicolenus dactylopterus were obtained using sectioned sagittal otoliths and maturity at length and age was estimated from probit analysis (Kelly et al., 1999). This study was carried out using samples from trawl surveys (1992-93). Age estimation of greater forkbeard Phycis blennoides, again using sectioned sagittal otoliths, formed the basis of a growth study (Kelly, 1997). Age estimates of greater argentine Argentina silus were obtained from whole otoliths and estimates of the von
Bertalanffy growth function were derived (Ronan et al., MS 1993). In addition this study provided information on age at maturity and fecundity of females in the range $23-45 \mathrm{~cm}$ total length. Age estimation of the black scabbardfish Aphanopus carbo was conducted using sectioned otoliths (EC FAIR, MS 1999). Biological and life history data for the squaliform sharks; leafscale gulper shark Centrophorus squamosus, birdbeak dogfish Deania calceus and Portuguese dogfish Centroscymnus coelolepis are given in Clarke (2000) and Clarke et al. (2001; 2002). Age estimates for the first two sharks were obtained from sectioned dorsal fin spines. Fecundity and size at maturity data were obtained from trawl and longline caught specimens. Age at maturity was not estimated directly for the sharks, but predicted from the von Bertalanffy growth function for $D$. calceus and from the mean length at estimated age for C. squamosus.

Life history data for shelf dwelling species were taken from several works and programs currently underway. Information on size, age, growth, maturity and fecundity of the epibenthic species, grey gurnard Eutrigla gurnardus from the Irish Sea was presented by Connolly (1986). Size and age data for the two pelagic species; Celtic Sea stock of herring Clupea harengus and the western/southern combined stocks of Atlantic mackerel Scomber scombrus were obtained from routine sampling programmes for these stocks. This information was used to derive the parameters of the von Bertalanffy growth function for both. Maturity data at size and age for both pelagic stocks were analysed by probit analysis to provide estimates of length and age at $50 \%$ maturity. It should be noted that the Celtic sea stock of $C$. harengus is composed of autumn and winter spawners. Therefore fish spawned in October, for example, are assigned to the age-class of fish hypothetically spawned on the following $1^{\text {st }}$ April. Data for cod Gadus morhua were obtained from information used in the ICES working group on the assessment of northern shelf demersal stocks (Officer, pers. comm., Irish Marine Institute, Dublin) whilst reproductive data were derived from a detailed study reported in Anon. (MS 1995a).

These data were used to derive further biological variables for these species. The ratios of size and age at maturity to maximum size and age were derived. These provide a more meaningful indication of when in the fishes growth or life span maturity actually is attained. Estimates of natural mortality in this study (Table 1) were obtained from the method that assumes that this is the rate required to reduce a recruited population to $1 \%$ of its initial value (Annala and 
TABLE 1. Life history parameters of the deepwater and continental shelf-dwelling species derived from Irish Marine Institute studies. The parameters are; maximum size and size at $50 \%$ maturity $(\mathrm{cm})$, maximum age and age at $50 \%$ maturity (yr.), Brody growth coefficient $(\mathrm{K})$ in $\mathrm{yr}^{-1}$, ratio of size and age at $50 \%$ maturity to maximum observed values, and the instantaneous rate of natural mortality (M). Maximum size and age are as observed in these studies.

\begin{tabular}{|c|c|c|c|c|c|c|c|c|c|}
\hline Species & Sex & $L_{\max }$ & Age $_{\text {max }}$ & $L_{50}$ & $\mathrm{Age}_{50}$ & $K$ & $L_{50} / L_{\max }$ & $\mathrm{Age}_{50} / \mathrm{Age}_{\max }$ & M \\
\hline Argentina silus & $\mathrm{F}$ & 45 & 36 & 26 & 4 & 0.14 & & 0.11 & 0.13 \\
\hline Aphanopus carbo & & 118 & 32 & & & & & & 0.14 \\
\hline Coryphaenoides rupestris & M & $23 *(106)$ & 50 & $10 *(48)$ & & 0.13 & 0.43 & & 0.09 \\
\hline Coryphaenoides rupestris & $\mathrm{F}$ & $24 *(111)$ & 60 & $12 *(57)$ & 10 & 0.1 & 0.5 & 0.16 & 0.08 \\
\hline Centrophorus squamosus & $\mathrm{F}$ & 145 & 70 & 128 & 44 & & 0.88 & 0.62 & 0.07 \\
\hline Centrophorus squamosus & M & 122 & 53 & 102 & 25 & & 0.83 & 0.47 & 0.09 \\
\hline Deania calceus & $\mathrm{F}$ & 119 & 35 & 105 & 27.5 & 0.07 & 0.86 & 0.78 & 0.13 \\
\hline Deania calceus & M & 109 & 31 & 58 & 19 & 0.13 & 0.78 & 0.61 & 0.16 \\
\hline Helicolenus dactylopterus & M & 38 & 43 & 26 & 15.5 & 0.06 & 0.59 & 0.36 & 0.11 \\
\hline Helicolenus dactylopterus & $\mathrm{F}$ & 39 & 37 & 23 & 13 & 0.09 & 0.58 & 0.35 & 0.12 \\
\hline \multicolumn{10}{|l|}{ Clupea harengus } \\
\hline Celtic Sea stock & $\mathrm{F}$ & 33 & 11 & 20 & 1 & 0.56 & 0.59 & 0.09 & 0.42 \\
\hline Scomber scombrus & $\mathrm{F}$ & 46 & 21 & 29 & 1.5 & & & & \\
\hline Western/southern stock & & & & & & 0.34 & 0.63 & 0.07 & 0.22 \\
\hline Gadus morhua & $\mathrm{F}$ & 100 & 10 & 50 & 2 & & & & \\
\hline Irish Sea stock & & & & & & 0.43 & 0.5 & 0.11 & 0.46 \\
\hline Eutrigla gurnardus & $\mathrm{F}$ & 39 & 21 & 18 & 1.5 & 0.21 & 0.46 & 0.08 & 0.22 \\
\hline
\end{tabular}

* Length measurements for Coryphaenoides rupestris are pre-anus length, with total length in parenthesis. All other measurements are total length apart from Eutrigla gurnardus which are fork length.

Sullivan, MS 1996). In the present case, maximum age was taken to be the greatest observed age in samples. Estimates of fecundity and age at maturity were used to derive the potential rate of population increase the surrogate $r^{1}$ - (Jennings et al., 1998) as follows:

$$
\begin{gathered}
r^{1}=\ln \text { (fecundity at length at } 50 \% \text { maturity) } / \\
\text { age at } 50 \% \text { maturity }
\end{gathered}
$$

Fecundity at size at maturity was used for A. silus and $C$. rupestris, but for the sharks mean observed ovarian fecundity was used because there was no evidence of increased fecundity with size (Clarke, 2000; Girard and Du Buit, 1999). Age at maturity was not estimated directly for the sharks but predicted from the von Bertalanffy growth function for $D$. calceus and from mean length-at-age in the case of C. squamosus.
A Beverton and Holt (1957) yield-per-recruit analysis was carried for two hypothetical species, one with a $\mathrm{K}$ strategist life history, and the other with a more r-selected mode. This model assumes that fish growth is expressed by the von Bertalanffy growth function and that mortality is exponential (Ricker, 1975).

\section{Results}

Length and age data of the deepwater species are presented in Table 1 along with those of the shelf species. Maximum age attained (longevity) by these deepwater species varies. The shortest-lived species was Phycis blennoides attaining ages of 9 years. The species that was estimated to reach the greatest age was C. squamosus, attaining an age of 70 years. C. rupestris was another long-lived species (60 years). 
Species with intermediate longevity were, in decreasing order, Helicolenus dactylopterus (43 years), A. silus (36 years), D. calceus (35 years) and A. carbo (32 years). The maximum ages reported were as determined from the studies outlined above. Apart from the work carried out for C. rupestris (Gordon et al., MS1995b) and E. gurnardus (Connolly, 1986) where marginal increment analysis was employed, these studies did not include any validation of age estimates obtained.

Greatest age at $50 \%$ maturity was recorded for H. dactylopterus (15.5 years), though maturity was attained by this species at a smaller size than the other species except for P. blennoides. Phycis blennoides reached maturity at smaller size and age than any of the other species. A. silus (4 years) also matures early, whilst $C$. rupestris matured later (10 years). The deepwater species were longer lived than the shelf species and thus the estimates of natural mortality for the deepwater species were lower. The Brody growth coefficients $(\mathrm{K})$ of the deepwater species indicate that they grow more slowly, reaching asymptotic size at a lower rate than the shelf species. Species displaying fastest growth, in terms of the Brody growth coefficient $(\mathrm{K})$ from the von Bertalanffy growth model was P. blennoides, followed by A. silus. Whilst C. rupestris displayed slow growth, the slowest growing of all species examined was $H$. dactylopterus, displaying slower growth than the shark $D$. calceus.

A more useful biological parameter than length or age at which $50 \%$ of the population reaches maturity is one that provides an indication of the point in the life history of that species when it reaches sexual maturity. Table 1 presents length and age at 50\% maturity as ratios of maximum length and age in each case. Maturity was reached at largest proportion of maximum size in the case of C. squamosus ( 83 and $88 \%$ for males and females respectively). The other sharks also mature at high proportions of maximum length. Coryphaenoides rupestris mature at around $50 \%$ of maximum length but in terms of age at only about $18 \%$ of maximum. Helicolenus dactylopterus also attained maturity at an advanced size, though at an earlier percentage of maximum age than C. rupestris. The shelf dwelling species all reached sexual maturity at relatively small size and early age, in all cases first maturity being reached at less than 2 years. In contrast, of the deepwater species only C. rupestris matured at less than $50 \%$ of maximum size. Contrasting patterns of maturity with respect to age are also apparent. The shelf-dwellers all matured in the first $12 \%$ of their life spans. Apart from C. rupestris the deepwater species reached maturity between $20 \%$ and $70 \%$ of their life spans. Fecundity estimates were only available for two of the teleosts. Argentina silus females in the range $26.5-45 \mathrm{~cm}$ total length had fecundities in the approximate range 4478 to 16284 . Coryphaenoides rupestris in the range 63$95 \mathrm{~cm}$ total length had fecundities in the approximate range 11000 to 55000 .

The potential rate of population increase for four deepwater species and four shelf-dwelling species is presented in Table 2, in order of increasing rate. These values show that the deepwater species all have slower rates of population increase than the shelf-dwelling species. The lowest rates of all are those of the sharks.

The Beverton and Holt yield-per-recruit simulations show some important differences between fisheries based on $K$ and $r$ strategists. $K$ strategist-based fisheries produce maximum yield at lower rates of

TABLE 2. Surrogate potential population replacement rate for four deepwater species compared with four continental shelf-dwelling species, calculated as fecundity at $L_{50} / \mathrm{Age}_{50}$.

\begin{tabular}{lcrc}
\hline \hline Species & & & $r^{1}$ \\
\hline Centrophorus squamosus & Fecundity at $L_{50}$ & Age $_{50}$ & $\left(\ln \left(\right.\right.$ fecundity at $\left.L_{50} / \mathrm{Age}_{50}\right)$ \\
Deania calceus & 8 & 44 & 0.05 \\
Coryphaenoides rupestris & 13 & 26 & 0.10 \\
Argentina silus & 13083 & 10 & 0.95 \\
Eutrigla gurnardus & 4478 & 1.5 & 2.10 \\
Gadus morhua & 14347 & 2 & 6.38 \\
Clupea harengus & 913780 & 1 & 6.86 \\
Scomber scombrus & 40879 & 1.5 & 10.62 \\
\hline
\end{tabular}


fishing mortality than those based on $r$ strategists (Fig. 2). Thus, $r$ strategists may be harvested at higher rates of fishing mortality than those based on $K$ strategists. The parameters used as inputs to this analysis are given in Table 3.

\section{Discussion}

The percentage of maximum length at which maturity is reached was greatest in the case of the sharks (78-88\%), agreeing with mean values calculated for elasmobranchs by Frisk et al. (2001). The deepwater teleosts matured at lower percentages of maximum length with the values for $C$. rupestris and P. blennoides less than $55 \%$ and in the range for the shelf-dwelling species. The shelf-dwelling species appear to reach sexual maturity whilst somatic growth proceeds. The ratio of age at maturity to maximum age represents the portion of time and growth that takes place before the investment adults make in reproduction. Again the sharks had the highest values, indicating that they live most of their lives before they mature. These contrasts between shelf and slope spe-

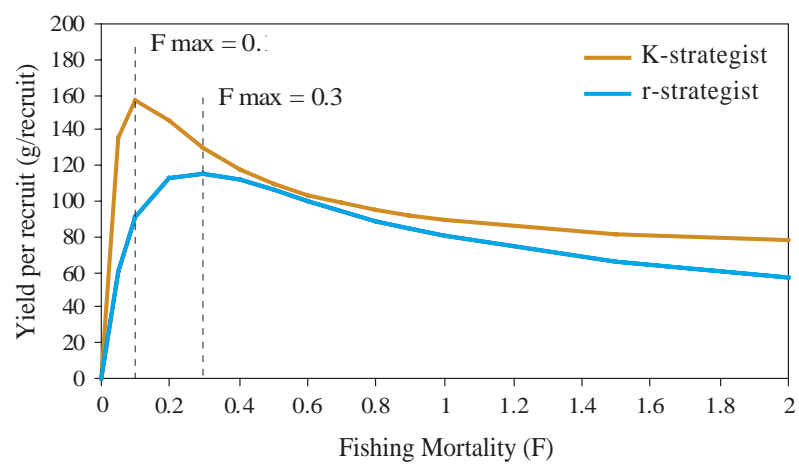

Fig. 2. Simulations of the Beverton and Holt yield-per-recruit model for hypothetical $K$ and $r$ strategist fish populations.

TABLE 3. Parameters used to fit Beverton and Holt (1957) yield-per-recruit model for hypothetical $K$ and $r$ strategist species. $M$, instantaneous rate of natural mortality, $\mathrm{K}$ in $\mathrm{yr}^{-1}$ the Brody growth coefficient and $W_{\infty}$ the asymptotic weight in grams from the von Bertalanffy growth function.

\begin{tabular}{lcc}
\hline \hline & $K$ strategist & $r$ strategist \\
\hline$M$ (natural mortality) & 0.09 & 0.2 \\
$K$ (Brody growth coefficient) & 0.08 & 0.37 \\
$W_{\infty}(\mathrm{g})$ & 2000 & 700 \\
\hline
\end{tabular}

cies agree well with published studies; Gordon et al. (1995a) notes that slope dwelling fish only mature when somatic growth has slowed or ceased, indicating that on the deepwater slopes, energy is available for growth or reproduction, but not both (Merrett and Haedrich, 1997). Estimates of the Brody growth coefficient $(K)$ for the deepwater species predict moderate to low rates of growth to asymptotic size.

The ratios of age at maturity to maximum age for sharks are similar to those reported for shelf elasmobranchs by Frisk et al. (2001). These authors tentatively suggest that compensatory responses to exploitation may explain earlier maturation in the sharks relative to other - unexploited - vertebrate classes. However, the likelihood that these species have gestation periods of more than one and perhaps more than two years (Girard, 2000) coupled with the possibility that they have prolonged periods of rest between reproductive events (Clark and King, MS 1989; Clarke et al., 2001) might indicate that the scope for compensatory change is limited. There have been reports of density dependent changes in fecundity in the shelf-dwelling squalid shark $S$. acanthias (Gauld, MS 1979). However C. coelolepis and $D$. calceus do not develop subsequent batches of oocytes during gestation. This seems to support the view that the scope for compensatory changes in deepwater sharks is more limited than might be the case for their shelf-dwelling relatives.

The dangers of not validating age have been illustrated by Beamish and McFarlane (1983). The errors in ageing the Pacific ocean perch Sebastes alutus led to a management strategy that was less conservative than was prudent, given the great longevity and low natural mortality of that stock. In the absence of tagging data, natural mortality is often estimated using the technique of Rikhter and Efanov (MS 1976), of Hoenig (1983) or that based on maximum age attained by a stock or species (Annala and Sullivan, MS 1996). The problems with using these approaches may be illustrated with reference to $A$. carbo. Morales Nin and Sena-Carvalho (1996) using whole otoliths found ages of up to 8 years whilst the results reported in this study, from sectioned otoliths, were up to 32 years. The resultant differences in estimates of $M$ from the method used in this study; 0.57 and 0.14 , respectively, give quite different ideas about maximum yield of this species. Again, the need for validation of age is underlined.

Available data on reproduction in teleosts further strengthens the contrasts between shelf and slope. 
Coryphaenoides rupestris and A. silus produce small numbers of large eggs (Kelly et al. 1996; Ronan et al., MS 1993) that are characteristic of species inhabiting low-energy environments (Ekau, 1991). There are difficulties in translating these fecundity data into annual egg production estimates. There have been several studies of reproduction in C. rupestris, but the results have been contradictory. The spawning is prolonged throughout the year (Allain, 2001; Bergstad, 1990; Gordon and Hunter, MS 1994; Kelly et al., 1996; Magnusson and Magnusson, 1995). However Kelly et al. (1996) found that this species was a determinate spawner, though Allain (2001) considers fecundity to be indeterminate and that the number of batches produced each year is unknown. Spawning in A. silus proceeds throughout the year (Magnusson, 1988; Ronan et al., MS 1993) though there may be seasonal peaks in spawning intensity (Anon., MS 1994). There is no published information on the nature of spawning in this species. Differing spawning strategies complicate comparisons between shelf and slope teleosts. Eutrigla gurnardus has an asynchronous strategy, spawning repeatedly throughout the breeding season (Connolly, 1986). Scomber scombrus also has a protracted spawning period (Anon., MS 1999). Thus, these species spread their reproductive effort over time to counteract environmental variability by adopting a "bet hedging" strategy (Lambert and Ware, 1984). This approach accommodates environmentally induced poor recruitment by increasing the temporal scale of reproductive output relative to that of the environmental fluctuation (Merrett and Haedrich, 1997).

The deepwater sharks have much lower fecundities than the slope-dwelling teleosts, but share similar values with shelf-based relatives such as S. acanthias (Holden and Meadows, 1964). These species produce a small number of well-developed young, with a better chance of survival. This tends to support the idea that stock-recruitment relationships are more defined in these viviparous elasmobranchs than may be the case for many teleosts.

This study illustrates the differences in growth and reproduction between shelf and slope. These differences might be illustrated using the concept of the $K-r$ continuum. $K$ strategists tend to inhabit environments where there is little fluctuation, they achieve success by attaining large size, deferred reproduction and producing smaller numbers of more developed offspring (Begon et al., 1996). However there has been much criticism of the $K-r$ concept. Stearns (1992) examines the evolution of life history traits and suggests that earlier authors had tended to consider that so-called $K$ strategists evolved under density-dependent conditions, while $r$ strategists evolved in densityindependent conditions, a theory that he considers incorrect. Boyce (1984) states that this theory should only be applied to density-dependent models, a point which Stearns (1992) also makes. The deficiencies in this concept should be noted. The use of the model in the current study is by way of a simple generalisation of the dichotomy in life-history strategies in these species, and does not consider the selection pressures on individual organisms that produced these traits.

The intrinsic rate of natural increase $(r)$ is the rate at which a population increases in size per individual in unit time. It is calculated as the mean number of offspring produced by an individual in its lifetime divided by the average time between the birth of an individual and the birth of the first offspring of that individual - cohort generation time - (Begon et al., 1996). Given the uncertainties in reproductive biology of deepwater teleosts and elasmobranchs, it was not possible to calculate $r$. However, following the method of Jennings et al. (1998), a surrogate value the potential rate of population increase $\left(r^{1}\right)$ - was derived from the available data for 4 deepwater species and 4 shelf species. In this approach, fecundity at age at maturity provides an index of reproductive output and age at maturity an index of cohort generation time (Jennings et al., 1999). Ranking the species according to $r^{1}$ suggests that the sharks are least resilient to fishing, followed by the slope teleosts. The shelf-dwellers display markedly higher rates of potential population increase. There are no published estimates of the intrinsic rate of population increase $(r)$ for the shelf species in this study. Jennings et al. (1998) state that $r$ could not be calculated for such species because available data were from stocks that had already been exploited, and reduced life-spans would bias the estimates. These authors suggest that $r^{1}$ is a useful surrogate, and produced estimates of this parameter for a range of shelf species. The parameter $r^{1}$ incorporates the fecundity at $L_{50}$, a surrogate for the mean annual egg production, and $\mathrm{Age}_{50}$, a substitute value for cohort generation time. Due to uncertainties in the estimates of annual egg-production (see above), $r$ was not calculated for the deepwater species, and the surrogate estimate $\left(r^{1}\right)$ was used instead.

Hoenig and Gruber (1990) suggested the possibility of ranking species according to their resilience 
to exploitation, based on life history characteristics. Smith et al. (1998) calculated "intrinsic rebound potentials" for 26 shark species, incorporating density dependence terms in their analyses. Brander (1981) ranked skate species according to the total mortality the populations could withstand without collapsing. This approach was also taken by Walker and Hislop (1998) for North Sea skates. Smith et al. (1998) note the difficulties in obtaining all the necessary data, therefore it seems prudent to maximise the usefulness of such information for assessment purposes.

These estimates of potential population increase suggest that these deepwater species are less resilient to fishing pressure and that they will respond more slowly to decreased exploitation than those on the continental shelf. The deepwater sharks share their very low rates of increase with shelf-dwelling sharks (Smith et al., 1998; Walker and Hislop, 1998) but the possibility that the deepwater sharks have very long gestation periods of 2 or more years (Girard, 2000) and the likelihood that they have prolonged resting periods between reproductive events (Clark and King, MS 1989; Clarke et al., 2001) may indicate that these deepwater elasmobranchs are yet more vulnerable than their shelf-based relatives.

Most deepwater fisheries on the continental slopes west of Ireland and Britain are multi-species in character, with the possible exception of the pelagic trawl fishery for $A$. silus (though data from this fishery are lacking). Figure 3 illustrates the interactions between the main gear types in terms of the main species in the catch. Coryphaenoides rupestris is taken in the multi-species trawl fisheries with a range of species including $A$. silus, deepwater sharks, A. carbo, Molva dypterygia and others (Charuau et al., 1995). Longline fisheries on the upper slopes target Molva molva and Brosme brosme (Anon., MS 2000) whilst deeper down another longline fishery targets Mora moro, Phycis blennoides and the sharks (Pineiro et al., 2001). The diversity of species in longline catches is less than from trawl, but sharks tend to dominate discards on longline (Connolly and Kelly, 1996). Orange roughy, Hoplostethus atlanticus, is taken in the mixed trawl fishery along with $C$. rupestris, but also in a directed fishery using specialised trawl gear, along with the cardinal, Epigonus telescopus.

Management of these fisheries should consider the vulnerability of each of the species. The ICES Working Group on the Biology and Assessment of Deep-sea Fisheries Resources has ranked the main deepwater species in order of their vulnerability, based on various life history parameters. In relation to these multi-species deepwater fisheries the question arises, how can a range of species be managed when they have a range of differing life history traits, though generally conforming to the $\mathrm{K}$ strategist mode?

The simulations based on Beverton and Holt's (1957) yield-per-recruit model (Fig. 2) show some important differences between species with what might

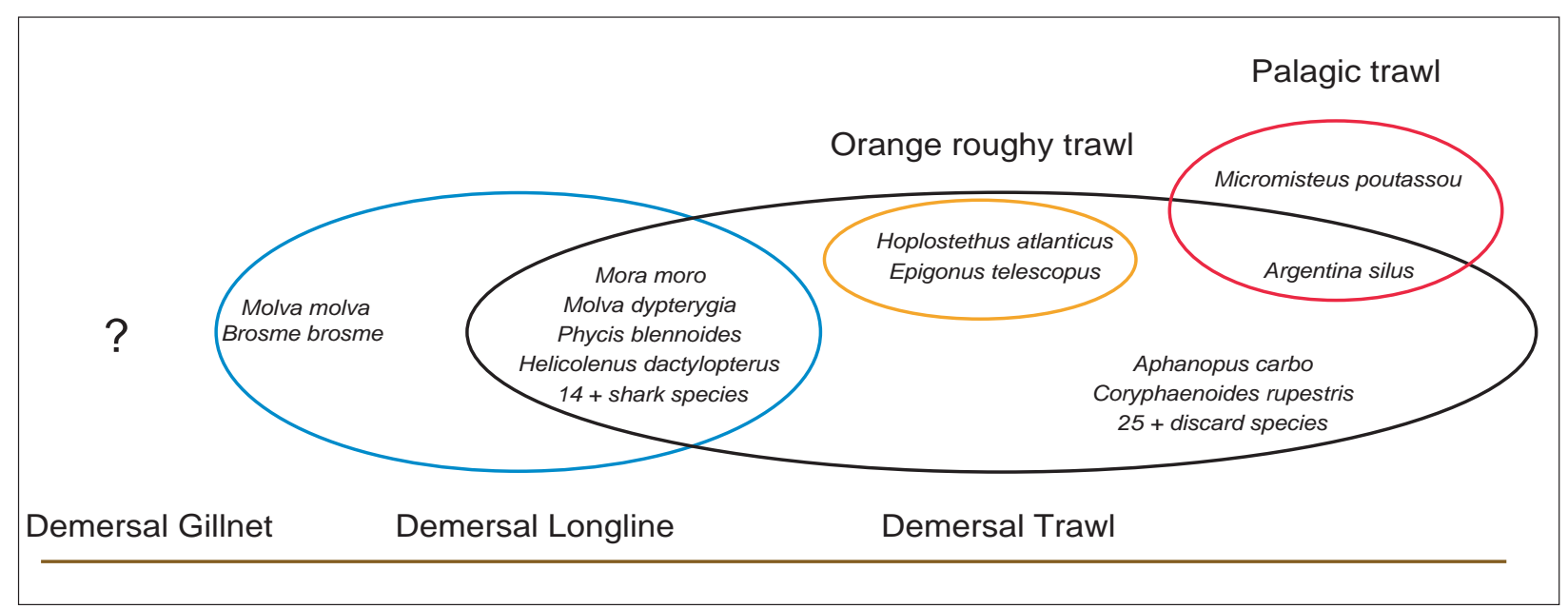

Fig. 3. Schematic representation of the interactions between the main deepwater fishing gear types in the area west of Ireland and Britain. Some species are caught by more than one gear. Data on by-catch in pelagic trawl fishery for Argentina silus are lacking. No data are available for gillnet fisheries. 
be termed $K$ strategist life histories and those with $r$ strategies. Fisheries based on $K$ strategists (such as the deepwater species in this study) achieve maximum yield at lower rates of fishing mortality $(F)$ than those based on $r$-strategists. Thus $r$-strategists (analogous to the shelf-dwelling species) can sustain higher fishing mortalities. The resilience of these species can be gauged by $r^{\prime}$ or preferably the intrinsic rate of population increase $r$. But depending on the rate of fishing mortality some species may decline, whilst others may sustain that level of exploitation. The lack of speciesspecific abundance indices may explain why, for example, well-known species such as Dipturus batis almost disappeared from the Irish Sea (Dulvy et al., 2000) whilst other skates were more resilient to fishing. This highlights the dangers of exploiting multispecies assemblages without taking into account the differing life-histories of the species involved. Framing management objectives may involve choosing the most vulnerable species and setting reference points for fishing mortality based on guidelines based on the precautionary approach. According to the results of this study and the ICES report on deepwater fisheries (Anon., MS 2001) the most vulnerable species in the exploited deepwater assemblage in the waters west of Ireland and Scotland are the deepwater squalid sharks.

The results presented in this paper support the widely held view that deepwater species are more vulnerable to exploitation than shelf-dwelling species, and that their response rates to decreased fishing mortality will be lower. There has been great debate both within ICES and European fisheries management agencies on appropriate management measures for deepwater species. The European Commission introduced a series of TACs, and effort controls and licencing of deepwater vessels. In June 2002, the EU agreed a series of TACs for a limited number of species. The ICES Advisory Committee on Fisheries Management has advised that a range of management measures may be required. The debate is now being carried to the Northeast Atlantic Fisheries Commission (NEAFC), which deals with management of fisheries outside coastal jurisdictions in the region. In 2003, NEAFC agreed a temporary limit of effort put into deepwater species in international waters.

The United Nations Food and Agriculture Organisation (FAO, 1995) presents guidelines for the adoption of the precautionary approach to fisheries management. These guidelines make reference to four "typical situations", but each is based on the level of exploitation of the fishery. With regard to deepwater fisheries perhaps it is now time to think more in terms of a "life history approach" where the biological traits of the species being caught are used in the formulation of management objectives. We echo the thoughts of Haedrich et al. (2001) that management plans for deepwater fisheries cannot follow those developed for traditional shelf stocks. Deepwater fisheries are based on species assemblages with completely different biological characteristics and this, calls for a new approach, based on life history information.

\section{Acknowledgements}

The data for this study were collected as part of the following European Commission funded projects; FAR Research Programme in the Fisheries Sector, EC Stride Operational Programme for Ireland and the EC FAIR Developing Deepwater Fisheries contract (coordinated by J. Gordon). The analysis was partly funded by the EU DGXIV Development of Elasmobranch Assessments contract (coordinated by H. Heessen). The crews of the survey vessels, De Linn, Mary M, Shannon, Sea Sparkle, Skarheim and Loran are thanked for their help whilst at sea. Deepwater surveys were funded by the Irish Marine Institute Survey Programme. N.-R. Hareide, J. Gordon, K. Yano, J. Bracken, L. Merin and A. Mahon helped this study in a variety of ways and are gratefully acknowledged.

\section{References}

ALLAIN, V. 2001. Reproductive strategies of three deep-water benthopelagic fishes from the northeast Atlantic Ocean. Fish. Res., 51: 165-176.

ANNALA, J. H. and K. J. SULLIVAN. MS 1996. Report from the fishery assessment plenary, April-May 1996: stock assessments and yield estimates. NIWA, Wellington. (Unpubl. report).

ANON. MS 1994. Report on the Study Group on the Biology and Assessment of Deep-sea Fisheries Resources. ICES C.M. Doc., No. 1995/Assessment:4, 91 p.

MS 1995a. Estimation of fish biomass in the Irish Sea by means of the annual egg production method. Belfast: Queen's University of Belfast. (Unpubl. report to European Commission).

MS 1999. Report of the Working Group on Mackerel and Horse Mackerel Egg Surveys. ICES C.M. Doc., No. G:5, 64 p.

MS 2000. Report on the biology and assessment of deep-sea fisheries resources. ICES C.M. Doc., No. ACFM:8, $206 \mathrm{p}$.

MS 2001. Report of the Working Group on Biology and Assessment of deep-sea Fisheries Resources. ICES C.M. Doc., No. ACFM:23, 47 p.

ATKINSON, D. B. 1995. The biology and fishery of 
roundnose grenadier (Coryphaenoides rupestris Gunnerus, 1765) in the north west Atlantic. In: Proceedings of NATO Advanced Workshop on deepwater fisheries of the north Atlantic Slope. A. L. Hopper (ed.). Kluwer, Amsterdam, p. 51-111.

BEAMISH, R. J. and G. A. MC FARLANE. 1983. The forgotten requirement for age validation in fisheries biology. Trans. Amer. Fish. Soc., 112(6): 735-743.

BEGON, M., J. L. HARPER and C. R. TOWNSEND. 1996. Ecology. Blackwell Scientific, London, 1068 p.

BERGSTAD, O. A. 1990. Distribution, population structure, growth and reproduction of the roundnose grenadier in the deep waters of the Skagerrak. Mar. Biol., 107: 25-39.

BEVERTON, R. J. H. and S. J. HOLT. 1957. On the dynamics of exploited fish populations. Fish. Inves., Series II, No. 19, 533 p.

BOYCE, M. S. 1984. Restitution of $r$ - and $K$ - selection as a model of density-dependent natural selection. Ann. Rev. Ecol. Syst., 15: 427-448.

BRANDER, K. 1981. Disappearance of Common skate Raja batis from the Irish Sea. Nature, 290: 48-49.

CHARUAU, A., H. DU POUY and P. LORANCE. 1995. French exploitation of the deep-water fisheries of the north Atlantic. In: Proceedings of NATO Advanced Workshop on deepwater fisheries of the north Atlantic Slope. A. L. Hopper (ed.). Kluwer, Amsterdam, p. 337-356.

CLARK, M. 2001. Are deepwater fisheries sustainable? - the example of orange roughy (Hoplostethus atlanticus) in New Zealand. Fish. Res., 51: 123-135.

CLARK, M. R. and K. J. KING. MS 1989. Deepwater fish resources off North Island New Zealand: results of a trawl survey, May 1985-June 1986. Ministry of Agriculture and Fisheries, New Zealand Fisheries Technical Report, No. 11.

CLARKE, M. 2000. Aspects of the biology of three exploited deepwater sharks Centrophorus squamosus, Centroscymnus coelolepis and Deania calceus (Elasmobranchii, Squalidae) from the continental slopes of the Rockall Trough and Porcupine Bank. Ph.D. Thesis, National University of Ireland, Dublin, $310 \mathrm{p}$.

CLARKE, M. W., P. L.CONNOLLY and J. J. BRACKEN. 2001. Aspects of reproduction of the deepwater sharks Centroscymnus coelolepis and Centrophorus squamosus from west of Ireland and Scotland. J. Mar. Biol. Ass. U.K., 81: 1019-1029.

2002. Age estimation of the exploited deepwater shark Centrophorus squamosus from the continental slopes of the Rockall Trough and Porcupine Bank. J. Fish Biol., 60: 501-514.

2002. Catch, discarding, age estimation, growth and maturity of the squalid shark Deania calceus west and north of Ireland. Fish. Res., 56: 139-153.

CONNOLLY, P. L. 1986. Aspects of the biology of the gurnard (Pisces; Triglidae) from the Irish Sea. Ph.D. Thesis, National University of Ireland, Dublin, 394 p.

CONNOLLY, P. L., N.-R. HAREIDE, and C. J. KELLY. 1996. Catch and discards from experimental trawl and longline fishing in the Rockall Trough. J. Fish Biol., 49 (Supplement A): 132-144.
CONNOLLY, P. L., C. K. KELLY and M. W. CLARKE. 1999. Longline survey of the eastern slopes of the Rockall Trough. Marine Institute Fisheries Leaflet, Dublin, No. 180.

DULVY, N. K., J. D. METCALFE, J. GLANVILLE, M. G. PAWSON and J. D. REYNOLDS. 2000. Fishery stability, local extinctions and shifts in community structure in skates. Cons. Biol., 14: 283-293.

EC FAIR. MS 1999. Developing deepwater fisheries. Scottish Association for Marine Sciences, Oban. Report to European Commission.

EKAU, W. 1991. Reproduction in high Antarctic fishes (Notothenioidei). Meerforschung, 33: 159-167.

FAO. 1995. Precautionary approach to fisheries. FAO Fish. Tech. Pap., No. 350, 152 p.

FRISK, M. G., T. J. MILLER and M. J. FOGARTY. 2001. Estimation and analysis of biological parameters in elasmobranch fishes: a comparative life history study. Can. J Fish. Aquat. Sci., 58: 969-981.

GAULD, J. MS 1979. Reproduction and fecundity of the Scottish-Norwegian stock of spurdog, Squalus acanthias (L.). ICES C.M. Doc., No. H:54, 21 p.

GIRARD, M. 2000. Distribution et reproduction de deux especes de requins de grands fonds, les $<<$ sikis $>>$, Centrophorus squamosus et Centroscymnus coelolepis exploites ddans l'Atlantique Nord-est. Ph.D. Thesis, Rennes: ENSAR.

GIRARD, M. and M. H. DUBUIT. 1999. Reproductive biology of two deep-water sharks from the British Isles, Centroscymnus coelolepis and Centrophorus squamosus (Chondrichthyes: Squalidae). J. Mar. Biol. Ass. U.K., 79: 923-931.

GORDON, J. D. M. 2001. Deep-water fish and fisheries: introduction. Fish. Res., 51: 105-111.

GORDON, J. D. M. and J. E. HUNTER. MS 1994. Study of deep water fish stocks to the west of Scotland. Scottish Association for Marine Science, Oban, (Unpubl. Report).

GORDON, J. D. M., N. R. MERRETT and R. L. HAEDRICH. 1995a. Environmental and biological aspects of slope dwelling fishes of the North Atlantic slope. In: Proceedings of NATO Advanced Workshop on deepwater fisheries of the north Atlantic Slope. A.L. Hopper (ed.). Kluwer, Amsterdam, p. 1-27.

GORDON, J. D. M., S. C. SWAN, C. J. KELLY and N.-R. HAREIDE. MS 1995b. Age determination of juvenile roundnose grenadier Coryphaenoides rupestris, a deep water macrourid fish: a preliminary report. ICES C.M. Doc., No. G:6, 6 p.

HAEDRICH, R. L., N. R. MERRETT and N. R. O'DEA. 2001. Can ecological knowledge catch up with deepwater fishing? A North Atlantic perspective. Fish. Res., 51: $113-122$.

HOENIG, J. M. 1983. Empirical use of longevity data to estimate mortality rates. Fish. Bull. US, 82: 898-903.

HOENIG, J. M. and S. H. GRUBER. 1990. Life-history patterns in the elasmobranchs: implications for fisheries management. NOAA Tech. Rep., NMFS, 90: 1-16.

HOLDEN, M. J. and P. S. MEADOWS. 1964. The fecundity of spurdog (Squalus acanthias L.) and its use for age 
determination. J. Mar. Biol. Ass. U.K., 42: 179-197.

JENNINGS, S., J. D. REYNOLDS and S. C. MILLS. 1998. Life history correlates of responses to fisheries exploitation. Proc. R. Soc. Lon., Series B, 265: 333-339.

JENNINGS, S., S. R. P. GREENSTREET and J. D. REYNOLDS. 1999. Structural change in an exploited fish community: a consequence of differential fishing effects on species with contrasting life histories. J. An. Ecol., 68: 617-627.

KELLY, C. J. 1997. Aspects of the biology of three deep water fish species from the continental slope of the Rockall Trough. Ph.D. Thesis, National University of Ireland, Dublin.

KELLY, C. J., P. L. CONNOLLY and J. J. BRACKEN. 1996. Maturity, oocyte dynamics and fecundity of the roundnose grenadier from the Rockall Trough. J. Fish Biol., 49 (Supplement A): 5-17.

1997. Age estimation, growth, maturity and distribution of the roundnose grenadier from the Rockall Trough. J. Fish Biol., 50: 1-17.

1999. Age estimation, growth, maturity and distribution of the bluemouth rockfish Helicolenus $d$. dactylopterus (Delaroche 1809) from the Rockall Trough. ICES J. Mar. Sci., 56: 61-74.

KELLY, C. J., P. L. CONNOLLY and M. W. CLARKE. MS 1998. The deepwater fisheries of the Rockall Trough: some insights gleaned from Irish survey data. ICES C.M. Doc., No. O:40, 22 p.

LAMBERT, T. C. and D. M. WARE. 1984 Reproductive strategies of demersal and pelagic spawning fish. Can. J. Fish. Aquat. Sci., 41: 1565-1569.

LANGEDAL, G. and N.-R. HAREIDE. MS 2000 Rapport fra Forsoksfiske med line pa Hatton Bank. Directorate of Fisheries, Bergen. (Unpubl. report).

MAGNUSSON. J. V.1988. On silver smelt (Argentina silus Asc.) in Icelandic wates. ICES C.M. Doc., No. G:39, 12 p. MAGNUSSON, J. V. and J. MAGNUSSON. 1995. The dis- tribution, relative abundance and biology of the deep-sea fishes of the Icelandic slope and Reykjanes Ridge. In: Deep-water Fisheries of the North Atlantic Oceanic Slope. A. G. Hopper (ed.) Kluwer, Amsterdam, p. 161-199.

MERRETT, N. R. and R. L. HAEDRICH. 1997. Deep-sea Demersal Fish and Fisheries. Chapman Hall, London. $283 \mathrm{p}$.

MORALES NIN, B. and D. SENA-CARVALHO. 1996. Age and growth of the black scabbardfish (Aphanopus carbo) off Madeira. Fish. Res., 25: 239-251.

PINEIRO, C. G., M. CASAS and R. BANON. 2001. The deepwater fisheries exploited by Spanish fleets in the Northeast Atlantic: a review of the current status. Fish. Res., 51: 311-320.

RICKER, W. E. 1975. Computation and interpretation of biological statistics of fish populations. Bull. Fish. Res. Board Can., No 191, 382 p.

RIKHTER, V. A. and V. N. EFANOV. MS 1976. On one of the approaches to estimation of natural mortality of fish populations. ICNAF Res. Doc., No. 8, Serial No. 3777 , $12 \mathrm{p}$.

RONAN, M. P., J. J. BRACKEN and J. P. MOLLOY. MS 1993. Determination of biological characteristics of the greater argentine (Argentina silus) west of Ireland and Scotland. University College Dublin, Dublin. Report to the Commission of the European Communities, No. MA 2.605 .

SMITH, A. E., D. W. AU. and C. SHOW. 1998. Intrinsic rebound potentials of 26 species of Pacific sharks. Mar. Freshw. Res., 49: 663-678.

STEARNS, S. C. 1992. The evolution of life histories. Oxford University Press, Oxford, $243 \mathrm{p}$.

WALKER, P. A. and J. R. G. HISLOP. 1998. Sensitive skates or resilient rays? Spatial and temporal shifts in ray species composition in the central and north-western North Sea between 1930 and the present day. ICES J. Mar. Sci., 55: 392-402. 